Article

\title{
Preliminary Calculation of the EROI for the Production of Crude Oil and Light Oil Products in Russia
}

\author{
Alexander Safronov and Anton Sokolov* \\ Laboratory of Geology of Oil and Gas Fields, Institute of Oil and Gas Problems SB RAS, \\ Oktyabrskaya 1, Yakutsk 677980, Russia; E-Mail: a.f.safronov@prez.ysn.ru \\ * Author to whom correspondence should be addressed; E-Mail: anton.new@mail.ru; \\ Tel.: +7-4112-390-620.
}

Received: 14 May 2014; in revised form: 25 July 2014 / Accepted: 25 August 2014 /

Published: 1 September 2014

\begin{abstract}
Russia is one of the world's largest producers of energy resources. The production of energy resources in Russia is profitable both economically and in terms of energy production. Currently, Russian oil and gas companies have a policy of increasing energy efficiency, which will led to an increase in the energy return on investment (EROI) of both oil and gas production as a whole, and of separate companies in particular. By our calculations, the EROI for oil production in Russia differs for the different companies, and in 2012 was in the range of 22-35:1. The EROI for light oil products in 2012 was in the range of 5-13:1.
\end{abstract}

Keywords: EROI; oil production; Russia

\section{Introduction}

Over the last 110 years, the annual consumption of energy resources in the world has increased 20 times from 0.6 in 1900 to 12.4 billion tons of oil equivalent (toe) in 2012 [1,2]. During the same time period, the structure of consumption of energy resources has changed significantly. The proportion of coal has been reduced from $90 \%$ in 1900 to $30 \%$ in 2012 ; and, at the same time, the proportion of oil and gas has increased to $33 \%$ and $24 \%$, respectively. Together, coal, oil and gas, in the structure of the consumption of primary energy resources, are about $87 \%$.

Oil and gas are considered non-renewable energy resources, which means that there will be a peak, and after peak production the availability of these resources will start to decrease. Many articles and 
books have been written in the last decade about peak oil, and the likelihood is that the world's production of traditional oil is now at a peak, with a maximum level of 75 million barrels a day [3]. It is known that hydrocarbons are produced for the purpose of obtaining energy and therefore, in line with data on volumes of production, it is important to know the EROI for production of those volumes. The energy return on investment (EROI) is the ratio of how much energy is gained from an energy production process compared to how much of that energy (or its equivalent from some other source) is required to extract, grow, etc. [4].

A large percentage of the research dedicated to the calculation of energy efficiency of production of various energy resources was published in recent years. In this regard, it should be noted that the Swiss online scientific journal Sustainability, in 2011, published 21 articles dedicated to the EROI. That issue posted the results of research and calculations of the EROI of oil and gas:

- Oil production in California from 1955 to 2005 [5];

- Oil and gas production in the USA. In 2007, the EROI for oil and gas production was about $11: 1[6]$;

- Production of ultradeep-water oil and natural gas in the Gulf of Mexico. In 2007, at the well-head the EROI ranged from 7-22:1 [7];

- Oil production in Norway. In later half of last the decade the EROI was about 40:1 [8];

- Preliminary calculation of the EROI for Oil Shale including internal energy is 2:1 [9];

- Oil production on the Daqing field, China. In 2009, the EROI was about 6.5:1 [10]

Russia is the largest oil-producing country and therefore it is important to calculate the energy efficiency of oil production in Russia.

The Federal bill No. 261 "On Energy Saving and Enhanced Energy Efficiency" was adopted in Russia at the end of 2009. The focus was "on energy saving and on the increase of energy efficiency". This bill talked about the need for an energy audit in industrial enterprises, including oil and gas production and processing. Therefore, oil companies that had not been keeping a systematic account of the consumed energy were now being compelled to account for the consumption of energy in all production sectors: exploration and production, logistic, processing, and sales. Some companies provided data on energy consumption in their annual reports, and based on that data, there is now an opportunity to calculate the EROI for oil production in Russia.

The purpose of this article is to calculate the EROI of oil production in Russia. For this purpose, the data published in official annual reports of the oil producing companies have been used.

\section{Data for the EROI Calculation}

\subsection{Hydrocarbon Production and Energy Consumption in Russia}

The Russian statistics agency provides data on hydrocarbon production and energy consumption for production and transportation of oil and gas. Open access data is available since 2005 (Table 1) [11].

Rosstat collects all the necessary information and forms an energy balance. On the balance sheet, there is data about oil and gas production as well as the total energy consumption for production of oil and gas combined. 
Table 1. Hydrocarbon production in Russia.

\begin{tabular}{|c|c|c|c|c|c|c|c|c|c|}
\hline No. & Title & 2005 & 2006 & 2007 & 2008 & 2009 & 2010 & 2011 & 2012 \\
\hline 1 & Production & & & & & & & & \\
\hline 1.1 & Oil production, Mt. & 470.0 & 480.3 & 490.7 & 487.8 & 494.1 & 505.1 & 512.2 & 518.5 \\
\hline 1.2 & Gas production, Mtoe & 516.9 & 529.4 & 525.5 & 535.6 & 471.0 & 525.4 & 541.1 & 528.1 \\
\hline 1.3 & Total production, Mtoe & 986.9 & 1009.6 & 1016.2 & 1023.4 & 965.0 & 1030.5 & 1053.3 & 1046.6 \\
\hline 2 & Consumption & & & & & & & & \\
\hline 2.1 & Energy resource, Mtoe & 8.9 & 8.9 & 13.1 & 12.3 & 9.5 & 9.1 & 8.5 & 10.1 \\
\hline 2.1 .1 & Gas & 8.8 & 8.7 & 12.7 & 11.7 & 9.2 & 8.7 & 8.3 & 10.0 \\
\hline 2.1 .2 & Oil & 0.1 & 0.1 & 0.4 & 0.6 & 0.3 & 0.3 & 0.1 & 0.1 \\
\hline 2.2 & Fuels, Mtoe & 1.6 & 1.9 & 1.6 & 1.5 & 1.1 & 1.5 & 0.8 & 0.7 \\
\hline 2.3 & Electricity, Mtoe & 14.2 & 16.4 & 17.1 & 18.5 & 18.9 & 19.7 & 20.8 & 21.7 \\
\hline 2.4 & Thermal Energy, Mtoe & 2.4 & 2.5 & 2.2 & 2.2 & 2.4 & 2.2 & 2.1 & 2.0 \\
\hline 2.5 & Total consumption, Mtoe & 27.2 & 29.6 & 34.0 & 34.5 & 31.9 & 32.4 & 32.2 & 34.5 \\
\hline
\end{tabular}

Energy consumption includes:

- Energy for drilling and construction;

- Energy for extraction and primal processing;

- Energy for transportation of hydrocarbons.

Unfortunately, there is no data on the energy consumption separated for each activity sector, as there is no data on embodied energy consumption. In the future, Rosstat's methodology of calculation energy consumption should be revisited and developed to show more data.

\subsection{Oil Producing Companies}

Not all Russian oil companies provide data on energy consumption in annual reports. The companies that do provide information on energy consumption are "Rosneft", "Bashneft", "Tatneft", "Gazprom Neft", and "TNK-BP” (which in 2013 merged with "Rosneft").

The companies that do not provide information on energy consumption are "Surgutneftegas", "Russneft", "Slavneft", and "Lukoil".

In Russia, there is no independent organization that makes an estimation of energy consumption in oil and gas companies. Therefore, it is hard to give any estimation about quality of data given in reports. At the moment, the data in reports is a black box and for the purpose of a deep analysis of the EROI we need to open it in order to understand how and what data is related to collecting, methodology, etc. Right now, we don't have access to that information. For the purpose of a preliminary calculation, we should trust this data (as far as we trust any information given in reports in general).

\subsubsection{OJSC Open Joint Stock Company “Gazprom Neft” (OJSC “Gazprom Neft”)}

"Gazprom Neft" is a vertically integrated oil company. Its main activities are the exploration, development, production and sale of oil and gas, as well as the production and sale of petroleum products. Proved reserves according to SPE (PRMS) at the end of 2012 were more than 1.2 Gtoe. The company operates in major oil and gas regions of Russia: Khanty-Mansi and Yamal-Nenets region, 
Tomsk, Omsk, Orenburg regions. "Gazprom Neft” has several projects outside of Russia, for example in Iraq and Venezuela.

"Gazprom Neft" in its annual reports provides data on the amount of consumed electricity and heat in sectors "exploration and production" and "processing" (Table 2) [12]. Data on material consumption is not published.

Table 2. Data from annual reports of OJSC "Gazprom Neft”.

\begin{tabular}{llccc}
\hline No. & OJSC “Gazprom Neft” & $\mathbf{2 0 1 0}$ & $\mathbf{2 0 1 1}$ & $\mathbf{2 0 1 2}$ \\
\hline 1 & Production figures & & & \\
\hline 1.1 & Oil production, Mt. & 31.1 & 31.5 & 32.9 \\
1.2 & Gas production, Gm ${ }^{3}$ & 3.6 & 7.3 & 8.7 \\
1.3 & Oil processing in Russia, Mt. & 35.1 & 38.1 & 39.2 \\
1.4 & The yield of light products & $63 \%$ & $60 \%$ & $59 \%$ \\
1.5 & Wells commissioned & 765 & 760 & 708 \\
1.6 & Average oil flow rate of existing wells, t/day & & 15.2 & 14.3 \\
\hline 2 & Energy consumption by sector & & & \\
\hline & Exploration and production & & & \\
2.1 & Electricity, GWh & 4886 & 4577 & 4902 \\
2.2 & Thermal energy, Tcal & 26.6 & 20.5 & 29.1 \\
& Processing, transportation and distribution & & & \\
2.3 & Electricity, GWh & 2.88 & 2.99 & 3.12 \\
2.4 & Thermal energy, Tcal & 3597 & 3895 & 4025 \\
\hline
\end{tabular}

\subsubsection{OJSC "Bashneft"}

OJSC "Bashneft" is a vertically integrated company engaged in production and processing of oil in Russia, which sells crude oil and petroleum products in the domestic and foreign markets. Proved reserves according to SPE (PRMS) classification at the end of 2012 increased to 2 billion barrels of oil. The main production region is the Republic of Bashkortostan.

Table 3. Data from annual reports of OJSC "Bashneft".

\begin{tabular}{llccc}
\hline No. & OJSC "Bashneft" & $\mathbf{2 0 1 0}$ & $\mathbf{2 0 1 1}$ & $\mathbf{2 0 1 2}$ \\
\hline 1 & Production figures & & & \\
\hline 1.1 & Oil production, Mt. & 14.1 & 15.1 & 15.4 \\
1.2 & Gas production, Gm ${ }^{3}$ & 0.41 & 0.45 & 0.42 \\
1.3 & Oil processing in Russia, Mt. & 21.2 & 21.1 & 20.8 \\
1.4 & The yield of light products & $61.8 \%$ & $59.9 \%$ & $59.7 \%$ \\
1.5 & Wells commissioned & 148 & 98 & 42 \\
1.6 & Average oil flow rate of existing wells, t/day & 2.5 & 2.8 & 2.9 \\
\hline 2 & Energy consumption by sector & & & \\
\hline & Exploration and production & & 2821 & 2886 \\
2.1 & Electricity, GWh & & 260 & 388 \\
2.2 & Thermal energy, Tcal & & 2790 & 2893 \\
& Processing, transportation and distribution & & 7086 & 7288 \\
\hline
\end{tabular}


Annual reports since 2011 provide data on energy consumption by sector of activity (Table 3) [13]. Data on material consumption is not published.

\subsubsection{OJSC "Rosneft"}

"Rosneft" is the largest oil producing company in Russia. After the merger with "TNK-BP", "Rosneft" has become one of the largest companies in the world. The geography of "Rosneft" in sector "exploration and production" covers the major oil and gas provinces of Russia, Western Siberia, Southern and Central Russia, Timan-Pechora, Eastern Siberia, the Far East and the Arctic offshore. The company also has projects in Kazakhstan, Algeria, Venezuela and in the United Arab Emirates. Proved reserves according to PRMS classification at the end of 2012 increased to $2.5 \mathrm{Gt}$.

The company's annual report provides a significant amount of data but, unfortunately, little attention is paid to issues of energy consumption. The reports only published the value of energy consumption for the whole company without a separation by sector of activity (Table 4) [14]. Data on material consumption is not published.

Table 4. Data from annual reports of OJSC "Rosneft".

\begin{tabular}{llccc}
\hline No. & OJSC "Rosneft" & $\mathbf{2 0 1 0}$ & $\mathbf{2 0 1 1}$ & $\mathbf{2 0 1 2}$ \\
\hline 1 & Production figures & & & \\
\hline 1.1 & Oil production, Mt. & 115.8 & 118.7 & 122 \\
1.2 & Gas production, Gm ${ }^{3}$ & 12.34 & 12.79 & 16.39 \\
1.3 & Oil processing in Russia, Mt. & 50.5 & 50.5 & 50.9 \\
1.4 & The yield of light products & $55.8 \%$ & $56.6 \%$ & $56.7 \%$ \\
1.5 & Wells commissioned & 871 & 1053 & 1183 \\
1.6 & Average oil flow rate of existing wells, t/day & 14.9 & 15.2 & 18.2 \\
\hline 2 & Total energy consumed, ktoe. & 6069.7 & 6304.9 & 6641.6 \\
\hline
\end{tabular}

\subsubsection{OJSC "TNK-BP”}

In 2013, the merger of "Rosneft" and "TNK-BP" was completed; and subsequently "TNK-BP" does not exist anymore. Nevertheless; we can make an EROI calculation based on the published 2012 annual report.

"TNK-BP" had been in the top three among Russian oil companies. At the end of 2012, "TNK-BP" had oil reserves of 9.8 billion barrels. Production units of the company located in Western and Eastern Siberia and the Volga-Urals region. Note that "TNK-BP" was developing one of the largest oil fields in the world, the Samotlor oil field.

In the report for 2012, as in the case with "Rosneft", data is provided on the energy consumption for the whole company, without separation by sectors (Table 5). Data on material consumption is not published [15]. 
Table 5. Data from annual report of OJSC "TNK-BP”.

\begin{tabular}{llccc}
\hline No. & OJSC "TNK-BP” & $\mathbf{2 0 1 0}$ & $\mathbf{2 0 1 1}$ & $\mathbf{2 0 1 2}$ \\
\hline 1 & Production figures & & & \\
\hline 1.1 & Oil production, Mt. & 73.8 & 74.6 & 74.9 \\
1.2 & Gas production, Gm ${ }^{3}$ & 12.8 & 14.1 & 14.8 \\
1.3 & Oil processing in Russia, Mt. & 24.3 & 24.5 & 25 \\
1.4 & The yield of light products & $57 \%$ & $54 \%$ & $54 \%$ \\
1.5 & Wells commissioned & 580 & 651 & 527 \\
1.6 & Average oil flow rate of existing wells, t/day & & & 12.8 \\
\hline 2 & Energy consumption & & \\
\hline 2.1 & Electricity, GWh & & & 12,742 \\
2.1 & Thermal energy, Tcal & & 1271 \\
2.3 & Fuel, $\mathrm{kt}$ & & 1.2 \\
2.4 & Gas, Gm ${ }^{3}$ & & 1.3 \\
\hline
\end{tabular}

\subsubsection{OJSC "Tatneft"}

The company "Tatneft" is a Russian oil and gas company. The main reserve is historically located in the territory of the Republic of Tatarstan. In addition, the company outside Tatarstan operates in Samara, Orenburg, Ulyanovsk region, Nenets Autonomous Okrug, and the Republic of Kalmykia. Proved reserves at the end of 2012 increased to $869 \mathrm{Mt}$.

Unlike other companies, "Tatneft" provides a specific consumption of energy per 1 ton of crude oil production [16]. The consumption of heat energy is not available as well as data on material consumption (Table 6).

Table 6. Data from annual report of OJSC "Tatneft".

\begin{tabular}{llccc}
\hline No. & OJSC "Tatneft" & $\mathbf{2 0 1 0}$ & $\mathbf{2 0 1 1}$ & $\mathbf{2 0 1 2}$ \\
\hline 1 & Production figures & & & \\
\hline 1.1 & Oil production, Mt. & 25.8 & 25.9 & 26.005 \\
1.2 & Gas production, Gm ${ }^{3}$ & 0.77 & 0.79 & 0.84 \\
1.4 & Wells commissioned & 331 & 309 & 326 \\
1.5 & Average oil flow rate of existing wells, t/day & & 3.8 & 3.8 \\
1.6 & Specific energy consumption, kwh/t. oil & 118.5 & 117.7 & 116.5 \\
\hline
\end{tabular}

We have to say that very little data is given on energy consumption and no data on material consumption, equipment purchasing. Because of that, we cannot perform an in-depth EROI analysis. It can be performed with the following additional data:

(1) Separate data on energy consumption by sectors: drilling, construction, oil extraction, transportation, and processing;

(2) Data on material consumption: steel and cement for wells and on-field pipeline;

(3) Data on field equipment.

At this moment, we only can give an estimation of the steel and cement used to complete wells. There is no data in the public domain on the purchasing of on-field equipment for each company. The 
only way to get this data and calculate embodied energy is to cooperate with companies' representatives. It can be done in the future. In this article, we will not do any estimation on equipment issue because this estimation will be too speculative.

\section{EROI Methodology}

There are three approaches to calculating EROI [4], which have been repeatedly spoken of in previously published articles. The first consists of calculating the energy spent for production which is expressed in energy units ( $\mathrm{kWh}, \mathrm{Gcal}$, fuel tons, etc.) and then relating it to an extracted volume of energy. However, it often happens that there is no data on the consumption of energy. In this case, it is possible to utilize the second approach, and calculate EROI through energy intensities. The second approach is used more often as it often appears too difficult to obtain data on consumption of energy and materials. The third way is to use a combined approach.

In this article, we will focus on first method.

\subsection{EROI Methodology for Oil Production}

As it was written in previous articles, definition and general formula of the EROI calculation for life time of any energy project is following [17]:

$$
\text { EROI }=\frac{E_{g}}{E_{c}+E_{o p}+E_{d}}
$$

where

$\mathrm{E}_{\mathrm{g}}$ - energy gained;

$\mathrm{E}_{\mathrm{c}}$ - energy input to construction;

$\mathrm{E}_{\mathrm{op}}$ - energy required to operate and maintain the project;

$\mathrm{E}_{\mathrm{d}}$ - energy required for decommissioning.

The most difficult question is what to consider as "energy input" for each project's stage? There are 5 boundaries for energy inputs and for each boundary special EROI is determined:

(1) Direct energy and material inputs $\left(\mathrm{EROI}_{1, \mathrm{~d}}\right)$;

(2) Direct and indirect energy and material inputs (EROI stnd $\left._{2}\right)$;

(3) Direct and indirect energy and material inputs and indirect labor consumption (EROI $\mathrm{I}_{1, \mathrm{lab}}$ );

(4) Direct and indirect energy and material inputs, indirect labor consumption and auxiliary services consumption $\left(\mathrm{EROI}_{1, \mathrm{aux}}\right)$;

(5) Direct and indirect energy and material inputs, indirect labor consumption, auxiliary services consumption and environmental $\left(\mathrm{EROI}_{1, \mathrm{env}}\right)$.

In this article, we will calculate the $\mathrm{EROI}_{1, \mathrm{~d}}$, but first we must specify all energy inputs for the oil field development project. The energy and materials inputs for following activities will be considered as "direct":

(1) Construction:

- Drilling rig mobilization, site prep, demobilization; 
- Well drilling;

- Well completion;

- Steel for well casing;

- Concrete for well casing;

- On-site engines and similar equipment;

- Steel and construction for associated necessary pipelines.

(2) Operation

- Electricity used for oil extraction;

- Electricity used for oil primary processing;

- Thermal energy used for heating;

- Energy and materials for additional drilling and construction;

- Energy and materials for repairs.

(3) Decommission

- Energy and material used for decommissioning.

All activities can be divided in three stages of oil field development project (Figure 1).

Figure 1. Energy input and output from an oil field development project.

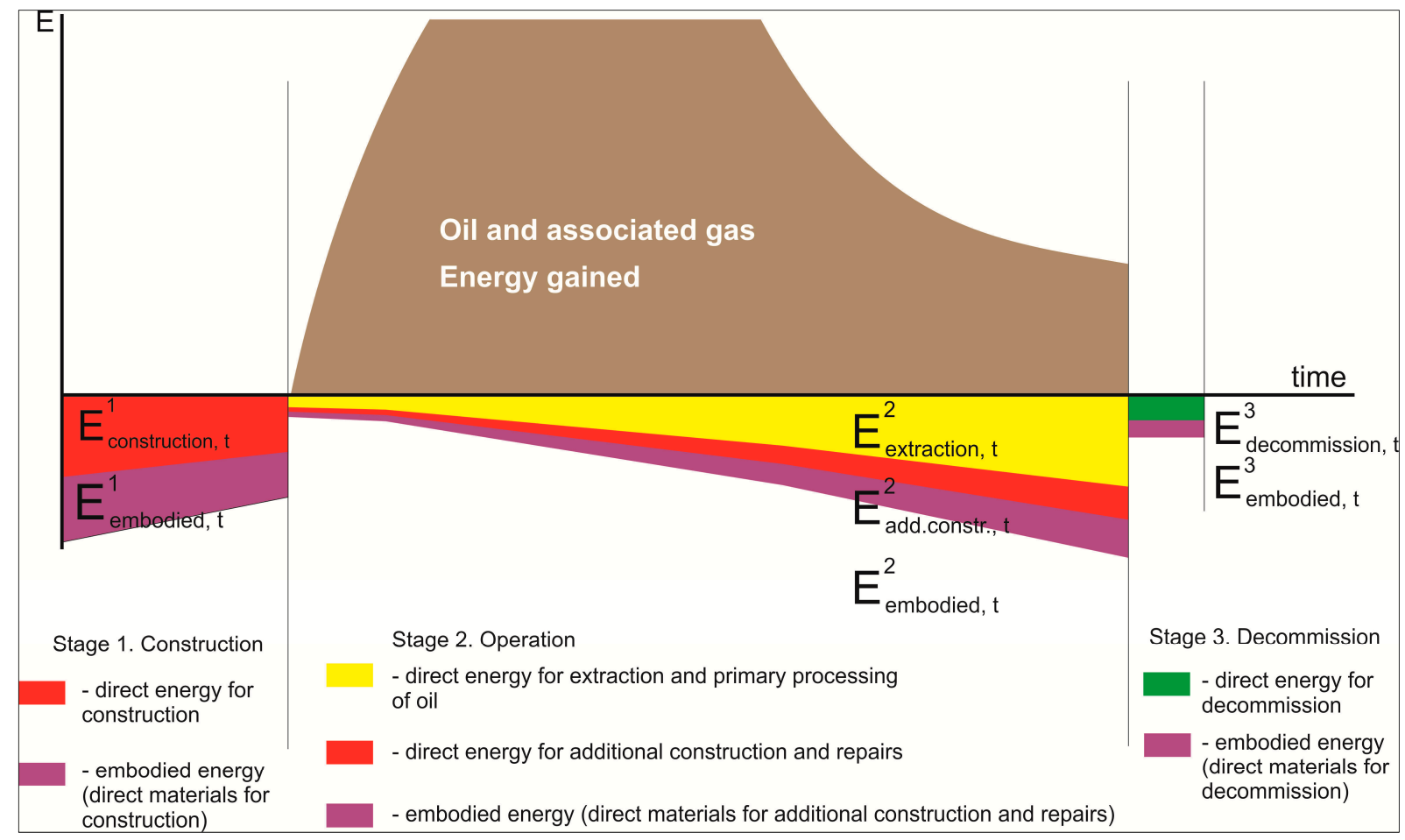

Base on the scheme we can specify EROI formulas for oil production:

(1) EROI for extraction in one year:

$$
\text { EROI }^{\text {extr }}(t)=\frac{E_{g}(t)}{E_{\text {extr }}^{2}(t)}
$$


$\mathrm{EROI}^{\text {extr }}(\mathrm{t})$ shows the impact of reserves depletion on energy profitability of project. It can be very useful to exclude all additional energy which is needed to drill new wells etc., to see how reserves depletion influences on energy efficiency.

(2) EROI for field development per year:

$$
\operatorname{EROI}^{\mathrm{dev}}(\mathrm{t})=\frac{\mathrm{E}_{\mathrm{g}}(\mathrm{t})}{\mathrm{E}_{\text {extr }}^{2}(\mathrm{t})+\mathrm{E}_{\text {add.constr. }}^{2}(\mathrm{t})+\mathrm{E}_{\text {embodied }}^{2}(\mathrm{t})}
$$

EROI $^{\mathrm{dev}}(\mathrm{t})$ shows the impact of reserves depletion and intensity of additional construction on energy profitability of project. Depending on drilling and construction intensity it can significantly vary from year to year.

(3) EROI final for all life time (or for certain years of project's life)

$$
\mathrm{EROI}^{\mathrm{final}}=\frac{\sum \mathrm{E}_{\mathrm{g}}}{\sum \mathrm{E}^{1}+\sum \mathrm{E}^{2}+\sum \mathrm{E}^{3}}
$$

where

(1) $\sum \mathrm{E}^{1}=\sum \mathrm{E}_{\text {construction }}^{1}+\sum \mathrm{E}_{\text {embodied }}^{1}$

(2) $\sum \mathrm{E}^{2}=\sum \mathrm{E}_{\text {extraction }}^{2}+\sum \mathrm{E}_{\text {add.constr. }}^{2}+\sum \mathrm{E}_{\text {embodied }}^{2}$

(3) $\sum \mathrm{E}^{3}=\sum \mathrm{E}_{\text {decomm. }}^{3}+\sum \mathrm{E}_{\text {embodied }}^{3}$

EROI $^{\text {final }}$ shows energy result for life time of project. It should be noted that decommission energy costs can be calculated during project operation time.

\subsection{EROI Methodology for Production of Oil Light Products}

In order to calculate EROI for production of oil light products we must add to energy consumed for oil extraction energy for transportation and processing (Figure 2).

Figure 2. Operational energy input and output from an oil light products development project.

\begin{tabular}{|l|l|l|}
\hline \multicolumn{1}{|c|}{ Oil field } & \multicolumn{1}{c|}{ Pipeline (PL) } & Oil processing plant (OPP) \\
\hline$E_{\text {extraction, } \mathrm{t}}^{2}$ & $\mathrm{E}_{\text {transport, } \mathrm{t}}^{\mathrm{PL}}$ & $\mathrm{E}_{\text {processing, } \mathrm{t}}^{\text {OPP }}$ \\
$\mathrm{E}_{\text {add.constr., } \mathrm{t}}^{\mathrm{PL}}$ & $\mathrm{E}_{\text {add.constr., } \mathrm{t}}^{\mathrm{OPP}}$ & $\mathrm{E}_{\text {add.constr. } \mathrm{t}}^{\text {adp }}$ \\
$\mathrm{E}_{\text {embodied, } \mathrm{t}}^{2}$ & $\mathrm{E}_{\text {embodied, } \mathrm{t}}^{\mathrm{PL}}$ & $\mathrm{E}_{\text {embodied, } \mathrm{t}}^{\text {OPP }}$ \\
\hline
\end{tabular}

Base on the scheme we can specify EROI formulas for production of oil light products:

(1) EROI without costs for additional construction and materials:

$$
\text { EROI }^{\text {basic }}(t)=\frac{E_{\text {oil light prooducts }}(t)}{E_{\text {extr }}^{2}(t)+E_{\text {transport }}^{\text {pl }}(t)+E_{\text {processing }}^{\text {opp }}(t)}
$$


Calculation of EROI ${ }^{\text {basic }}$ can be useful for comparison production process of same or different motor fuels: corn ethanol, GTL, CTL.

(2) EROI with all energy and material costs.

$$
\text { EROI }^{\text {full }}(t)=\frac{E_{\text {oil light products }}(t)}{E^{2}(t)+E^{p l}(t)+E^{o p p}(t)}
$$

where

$$
\begin{aligned}
& E^{2}(t)=E_{\text {extr }}^{2}(t)+E_{\text {add.const. }}^{2}(t)+E_{\text {embodied }}^{2}(t) \\
& E^{p l}(t)=E^{p l}{ }_{\text {transp }}(t)+E^{p l}{ }_{\text {add.const. }}(t)+E^{p l} \text { embodied }(t) \\
& E^{\text {opp }}(t)=E^{\text {opp }}{ }_{\text {process }}(t)+E^{\text {opp }}{ }_{\text {add.const. }}(t)+E^{\text {opp }} \text { embodied }(t) \\
& \text { EROI }{ }^{\text {full }} \text { can be useful for comparison of different technologies for different motor fuels. } \\
& \text { In order to calculate the EROI, the following conversion factors will be used (Table } 7) \text {. }
\end{aligned}
$$

Table 7. Conversion factors.

\begin{tabular}{lll}
\hline Entity & MJ & Tons of Oil Equivalent \\
\hline 1 ton of oil & 41,868 & 1 \\
$1000 \mathrm{~m}^{3}$ of natural gas & 36,000 & 0.86 \\
For producing of $1 \mathrm{MWh}$ are used & - & 0.209 \\
For producing of $1 \mathrm{Gcal}$ are used & - & 0.992 \\
For production of $1 \mathrm{t}$ of steel are used & 31,250 & 0.746 \\
For production of $1 \mathrm{t}$ of cement are used & 5000 & 0.119 \\
\hline
\end{tabular}

It is necessary to note that comparisons of consumed electric power, thermal energy and an energy equivalent of fossil fuels is a very important issue. In Russia, the widespread practice of an assessment of the production efficiency of electric power and thermal energy is specific to the fuel consumption in the production of $1 \mathrm{kWh}$ and $1 \mathrm{Gcal}$. In our calculations, we will use the actual values of the consumption of fuel for production electric power and heat energy at OJSC "Tatneft" enterprises. The data is displayed in table above.

Data on the energy consumption for the production of steel and cement are taken from the report of British scientists from the University of Bath [18].

\subsection{Auxiliary Methodology}

There three special issues concerning the EROI calculation in this particular article which should be noted.

First, for Rosneft and TNK-BP we don't have data on energy consumption separate by activity sectors. This means in order to calculate the EROI we must perform separation as follows:

(1) Assume that the energy efficiency of oil processing in Rosneft and TNK-BP equals that of Gazprom Neft.

(2) Calculate the specific energy consumption for processing 1 ton of oil in Gazprom Neft. It is $10.2 \mathrm{~kg}$ of oil equivalent per ton of oil processed. 
Knowing the volume of oil processing by company and the specific energy consumption for processing of 1 ton of oil, we can calculate the amount of energy consumed in oil processing sector. After that, we can calculate the amount of energy consumed in oil production sector by subtracting energy consumed in processing sector from the amount of total energy consumed. Then we can calculate the EROI of hydrocarbon production and the EROI of production of light oil products.

Second, as it has been shown in above tables, volumes of oil produced are not equal to volumes oil processed. However, in order to perform the EROI for oil light we must take into calculation equal volumes. We will proceed as follows (Figure 3):

(1) Equalize volumes by notionally increasing or decreasing oil production.

(2) Proportionally change energy cost for production.

(3) Calculate the EROI for oil light products.

The following products of oil processing will be considered as oil light products:

- Gasoline;

- Diesel fuel;

- Aviation fuel.

Figure 3. Scheme of the energy return on investment (EROI) calculation for oil light products.

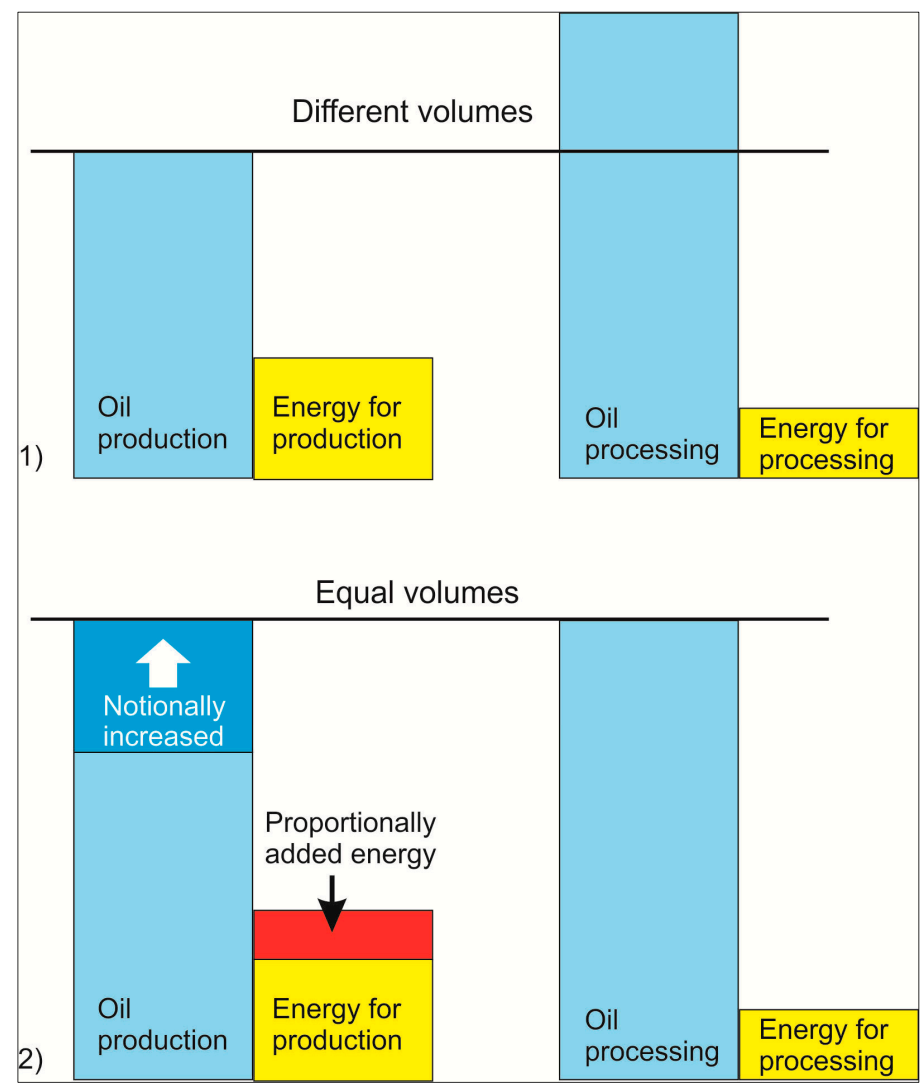

In this article because the lack of data formula of the EROI ${ }^{\text {basic }}$ for oil light products will be modified:

$$
\text { EROI basic mod. }(t)=\frac{E_{\text {oil processed }}(t) * K_{\text {yield of oil light products }}}{E_{\text {extr }}^{2}(t)+E_{\text {add.constr }}^{2}(t)+E_{\text {embodied }}^{2}(t)+E_{\text {transport }}^{\text {pl }}(t)+E_{\text {processing }}^{\text {opp }}(t)}
$$


Third, unfortunately, we do not have data on material consumption for oil production in the public domain. We only can give an estimation of steel and cement consumption basing on quantity of commissioned wells. We will count that each well requires about $180 \mathrm{mt}$ of steel and $200 \mathrm{mt}$ of cement. For accurate calculations, of course, we need official data. All companies have such data and it can be given in annual reports along with energy consumption.

In this article, we will not give an estimation of embodied energy, which is connected with additional on-field equipment because there is no data in public domain and assumptions as was said above will be very speculative.

\section{Results}

\subsection{EROI for Hydrocarbon Production in Russia}

According to Russian statistic agency data the EROI for oil and gas production and transportation is about 30 (Table 8, Figure 4).

Table 8. Hydrocarbon production in Russia.

\begin{tabular}{llcccccccc}
\hline No. & Title & $\mathbf{2 0 0 5}$ & $\mathbf{2 0 0 6}$ & $\mathbf{2 0 0 7}$ & $\mathbf{2 0 0 8}$ & $\mathbf{2 0 0 9}$ & $\mathbf{2 0 1 0}$ & $\mathbf{2 0 1 1}$ & $\mathbf{2 0 1 2}$ \\
\hline 1 & Production, Mtoe & 986.9 & 1009.6 & 1016.2 & 1023.4 & 965.0 & 1030.5 & 1053.3 & 1046.6 \\
2 & Energy consumption, Mtoe $^{27.2}$ & 29.6 & 34.0 & 34.5 & 31.9 & 32.4 & 32.2 & 34.5 \\
3 & EROI $^{\text {dev and transp }}$ & 36 & 34 & 30 & 30 & 30 & 32 & 33 & 30 \\
\hline
\end{tabular}

Figure 4. Hydrocarbon production in Russia, Mtoe (left scale) and EROI (right scale).

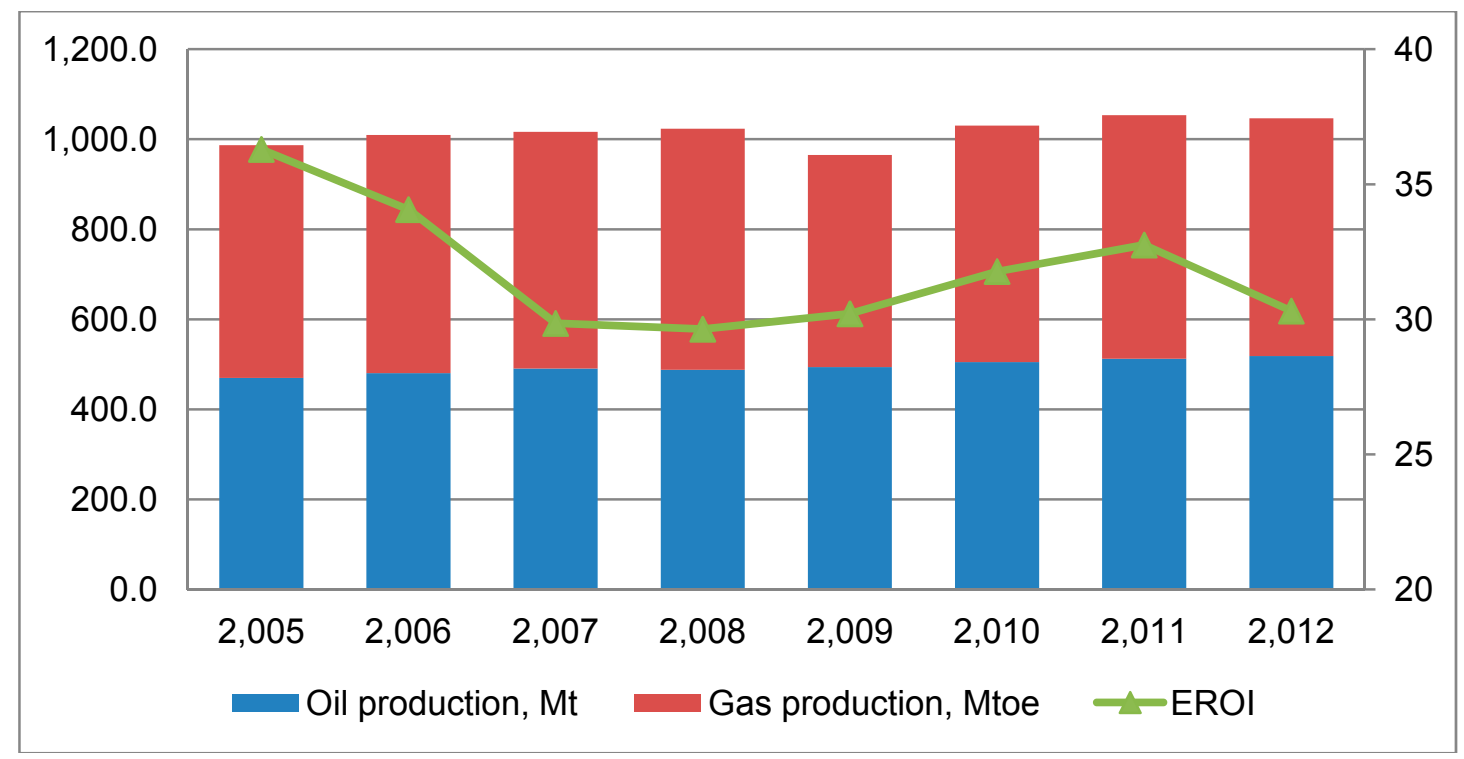

Obviously, with the depletion of reserves, production becomes more costly. The growth of energy consumption in turn leads to decrease the EROI. This is entirely consistent with the fact that until 2008 the EROI was continually declining. However, after 2008, the EROI increased from 30 to 33 . In our opinion, this increase is due to new energy strategies in all oil and gas companies. In addition, in 2012 it decreased to 30 . We believe this is mainly because of decreasing the EROI for gas production. Another factor is that the potential of energy saving is exhausting. 


\subsection{EROI for Oil and Oil Light Products Production in Companies}

\subsubsection{OJSC "Gazprom Neft”}

On the basis of data provided in the reports, we can calculate the EROI ${ }^{\mathrm{dev}}$ and EROI ${ }^{\text {basic mod. }}$ for OJSC “Gazprom neft” (Table 9).

Table 9. Calculation of the EROI for OJSC "Gazprom neft".

\begin{tabular}{|c|c|c|c|c|}
\hline No. & OJSC “Gazprom Neft” & 2010 & 2011 & 2012 \\
\hline 1 & $\mathrm{EROI}^{\mathrm{dev}}$ for hydrocarbon & & & \\
\hline 1.1 & Hydrocarbon production, ktoe. (Oil + gas) & 34,196 & 37,778 & 40,382 \\
\hline 1.2 & Energy consumption of sector "exploration and production", ktoe. & 1023.8 & 958.6 & 1027.4 \\
\hline 1.3 & Consumption of steel, ktoe. & 102.7 & 102.1 & 95.1 \\
\hline 1.4 & Consumption of cement, ktoe. & 18.2 & 18.1 & 16.9 \\
\hline 1.5 & EROI without embodied energy (1.1/1.2) & 33.4 & 39.4 & 39.3 \\
\hline 1.6 & EROI with embodied energy $(1.1 /(1.2+1.3+1.4))$ & 29.9 & 35.0 & 35.4 \\
\hline 2 & EROI $^{\text {basic mod. }}$ for light oil products & & & \\
\hline 2.1 & Oil production (equal to the volume of processing), ktoe. & 35,100 & 38,100 & 39,200 \\
\hline 2.2 & The yield of oil light products & $63 \%$ & $60 \%$ & $59 \%$ \\
\hline 2.3 & $\begin{array}{l}\text { Energy consumption of sector "exploration and production", ktoe. } \\
\text { (with proportionally added energy without embodied energy) }\end{array}$ & 1155 & 1159 & 1224 \\
\hline 2.4 & $\begin{array}{l}\text { Energy consumption of sector "exploration and production", ktoe. } \\
\text { (with proportionally added energy) }\end{array}$ & 1292 & 1304 & 1357 \\
\hline 2.5 & $\begin{array}{l}\text { Energy consumption of sector "processing, transportation and } \\
\text { distribution", ktoe. }\end{array}$ & 357 & 387 & 399 \\
\hline 2.6 & EROI without embodied energy $(2.1 \times 2.2 /(2.3+2.5))$ & 14.6 & 14.8 & 14.2 \\
\hline 2.7 & EROI with embodied energy $(2.1 \times 2.2 /(2.4+2.5))$ & 13.5 & 13.7 & 13.3 \\
\hline
\end{tabular}

In 2012, the EROI for hydrocarbon production by "Gazprom Neft" was 35.4, and this figure had been growing since 2010. Along with a simultaneous increase in production, it means that the company copes with the objective of improving the energy efficiency of hydrocarbon production. However, the EROI of oil light products along with increasing amounts of processing has a slight tendency to decrease.

\subsubsection{OJSC "Bashneft"}

On the basis of data provided in the reports, we can calculate the EROI ${ }^{\text {dev }}$ and EROI ${ }^{\text {basic mod. }}$ for OJSC "Bashneft" (Table 10).

The energy efficiency of hydrocarbon production of "Bashneft" in 2012 was 24.3 and the figure was slightly lower compared to 2011. The EROI is lower compared to Gazprom neft because of the fact that the company is producing oil from depleted fields. This is reflected in the low flow rate of wells and high water cut, 90.4\%, which is higher than Russia's average of 85.4\% [18]. With each year it takes more and more energy to produce the same volume of oil, and this tendency opposes efforts taken to improve energy efficiency. So far, the efforts made by the company allow it to keep the energy efficiency at an acceptable level. 
Table 10. Calculation of the EROI for OJSC "Bashneft".

\begin{tabular}{|c|c|c|c|c|}
\hline No. & OJSC "Bashneft" & 2010 & 2011 & 2012 \\
\hline 1 & EROI $^{\mathrm{dev}}$ for hydrocarbon & & & \\
\hline 1.1 & Hydrocarbon production, ktoe. (Oil and gas) & & 15,485 & 15,758 \\
\hline 1.2 & Energy consumption of sector “exploration and production", ktoe. & & 615.4 & 641.7 \\
\hline 1.3 & Consumption of steel, ktoe. & & 13.2 & 5.6 \\
\hline 1.4 & Consumption of cement, ktoe. & & 2.3 & 1.0 \\
\hline 1.7 & EROI without embodied energy (1.1/1.2) & & 25.2 & 24.6 \\
\hline 1.8 & EROI with embodied energy $(1.1 /(1.2+1.3+1.4))$ & & 24.5 & 24.3 \\
\hline 2 & EROI $^{\text {basic mod. }}$ for light oil products & & & \\
\hline 2.1 & Oil production (equal to the volume of processing), ktoe. & & 21,100 & 20,800 \\
\hline 2.2 & The yield of light products & & $59.9 \%$ & $59.7 \%$ \\
\hline 2.3 & $\begin{array}{l}\text { Energy consumption of sector "exploration and production", ktoe. } \\
\text { (with proportionally added energy without embodied energy) }\end{array}$ & & 859 & 866 \\
\hline 2.4 & $\begin{array}{l}\text { Energy consumption of sector "exploration and production", ktoe. } \\
\text { (with proportionally added energy) }\end{array}$ & & 875 & 873 \\
\hline 2.5 & $\begin{array}{l}\text { Energy consumption of sector "processing, transportation and } \\
\text { distribution", ktoe. }\end{array}$ & & 1286 & 1327 \\
\hline 2.6 & EROI without embodied energy $(2.1 \times 2.2 /(2.3+2.5))$ & & 5.9 & 5.7 \\
\hline 2.7 & EROI with embodied energy $(2.1 \times 2.2 /(2.4+2.5))$ & & 5.8 & 5.6 \\
\hline
\end{tabular}

\subsubsection{OJSC "Rosneft”}

On the basis of data provided in the reports, we can calculate the EROI ${ }^{\text {dev }}$ and EROI ${ }^{\text {basic mod. }}$ for OJSC "Rosneft" (Table 11).

Table 11. Calculation of the EROI for OJSC "Rosneft".

\begin{tabular}{llccc}
\hline No. & OJSC "Rosneft" & $\mathbf{2 0 1 0}$ & $\mathbf{2 0 1 1}$ & $\mathbf{2 0 1 2}$ \\
\hline 1 & EROI $^{\text {dev }}$ for hydrocarbon & & & \\
\hline 1.1 & Hydrocarbon production, ktoe. (Oil and gas) & 126,412 & 129,699 & 136,095 \\
\hline 1.2 & Energy consumption of sector "exploration and production", ktoe. & 5554.6 & 5789.9 & 6122.4 \\
\hline 1.3 & Consumption of steel, ktoe. & 117.0 & 141.4 & 158.9 \\
\hline 1.4 & Consumption of cement, ktoe. & 20.7 & 25.1 & 28.2 \\
\hline 1.5 & EROI without embodied energy $(1.1 / 1.2)$ & 22.8 & 22.4 & 22.2 \\
\hline 1.6 & EROI with embodied energy (1.1/(1.2+1.3+1.4)) & 22.2 & 21.8 & 21.6 \\
\hline 2 & EROI basic mod. for light oil products & & \\
\hline 2.1 & Oil production (equal to the volume of processing), ktoe. & 50,500 & 50,490 & 50,900 \\
\hline 2.2 & The yield of light products & $55.8 \%$ & $56.6 \%$ & $56.7 \%$ \\
\hline 2.3 & $\begin{array}{l}\text { Energy consumption of sector "exploration and production", ktoe. } \\
\text { (proportionally decreased without embodied energy) }\end{array}$ & 2422 & 2463 & 2554 \\
\hline 2.4 & $\begin{array}{l}\text { Energy consumption of sector "exploration and production", ktoe. } \\
\text { (proportionally decreased) }\end{array}$ & 2482 & 2534 & 2632 \\
\hline 2.5 & $\begin{array}{l}\text { Energy consumption of sector "processing, transportation and } \\
\text { distribution", ktoe. }\end{array}$ & 515.1 & 515.0 & 519.2 \\
\hline 2.6 & EROI without embodied energy (2.1 $\times 2.2 /(2.3+2.5))$ & 9.6 & 9.6 & 9.4 \\
\hline 2.7 & EROI with embodied energy $(2.1 \times 2.2 /(2.4+2.5))$ & 9.2 & 9.1 & 8.9 \\
\hline
\end{tabular}


As we can see, the energy efficiency of hydrocarbon production in the company Rosneft has a slight tendency to decrease, although the company has made great efforts to improve energy efficiency. However, despite all this, with the growth in production, energy consumption together with consumption of material is growing faster. At the moment, because the lack of data we cannot give an answer as to why the EROI is lower for "Gazprom neft" and for "Bashneft". In order to provide an answer we need detailed data on energy consumption.

\subsubsection{OJSC “TNK-BP”}

On the basis of data provided in the reports, we can calculate the EROI ${ }^{\mathrm{dev}}$ and EROI ${ }^{\text {basic mod. }}$ for OJSC “TNK-BP” (Table 12).

Because data is available only for 2012, it is not possible to analyze EROI dynamics. EROI values close to those of "Rosneft", so we can say that in terms of energy efficiency the two companies operate the same way.

Table 12. Calculation of the EROI for OJSC "TNK-BP”.

\begin{tabular}{|c|c|c|c|}
\hline No. & OJSC “TNK-BP” & 2010 & 2012 \\
\hline 1 & EROI $^{\mathrm{dev}}$ for hydrocarbon & & \\
\hline 1.1 & Hydrocarbon production, ktoe. (Oil and gas) & & 87,628 \\
\hline 1.2 & Energy consumption of sector "exploration and production", ktoe. & & 3768 \\
\hline 1.3 & Consumption of steel, ktoe. & & 70.8 \\
\hline 1.4 & Consumption of cement, ktoe. & & 12.5 \\
\hline 1.5 & EROI without embodied energy $(1.1 / 1.2)$ & & 23.3 \\
\hline 1.6 & EROI with embodied energy $(1.1 /(1.2+1.3+1.4))$ & & 22.8 \\
\hline 2 & EROI ${ }^{\text {basic mod. }}$ for light oil products & & \\
\hline 2.1 & Oil production (equal to the volume of processing), ktoe. & & 25,000 \\
\hline 2.2 & The yield of light products & & $54 \%$ \\
\hline 2.3 & $\begin{array}{l}\text { Energy consumption of sector "exploration and production", ktoe. } \\
\text { (without embodied energy with proportionally added energy) }\end{array}$ & & 1258 \\
\hline 2.4 & $\begin{array}{l}\text { Energy consumption of sector "exploration and production", ktoe. } \\
\text { (proportionally decreased) }\end{array}$ & & 1341 \\
\hline 2.5 & $\begin{array}{l}\text { Energy consumption of sector "processing, transportation and } \\
\text { distribution", ktoe. }\end{array}$ & & 255 \\
\hline 2.6 & EROI without embodied energy $(2.1 \times 2.2 /(2.3+2.5))$ & & 8.9 \\
\hline 2.7 & EROI with embodied energy $(2.1 \times 2.2 /(2.4+2.5))$ & & 8.5 \\
\hline
\end{tabular}

\subsubsection{OJSC "Tatneft"}

On the basis of data provided in the reports, we can calculate the EROI ${ }^{\mathrm{dev}}$ and EROI ${ }^{\text {basic mod. }}$ for OJSC "Tatneft" (Table 13).

The reports note that the company pays special attention to energy efficiency. Measures taken by the company are sufficient to ensure that the specific energy consumption was reducing, which is ultimately reflected in the fact that there is a trend of increasing EROI. Nevertheless, as mentioned 
above, to make an unambiguous conclusion there is not enough data, in example there is no data on thermal energy consumption.

Table 13. Calculation of the EROI for OJSC "Tatneft".

\begin{tabular}{llccc}
\hline No. & OJSC "Tatneft" & $\mathbf{2 0 1 0}$ & $\mathbf{2 0 1 1}$ & $\mathbf{2 0 1 2}$ \\
\hline 1 & EROI $^{\text {dev }}$ for hydrocarbon & & & \\
1.1 & Hydrocarbon production, ktoe. (Oil and gas) & 26,462 & 26,579 & 26,727 \\
1.2 & Energy consumption of sector "exploration and production", ktoe. & 639.0 & 637.1 & 633.2 \\
1.3 & Consumption of steel, ktoe. & 44.4 & 41.5 & 43.8 \\
1.4 & Consumption of cement, ktoe. & 3.9 & 3.7 & 3.9 \\
1.5 & EROI without embodied energy $(1.1 / 1.2)$ & 41.4 & 41.7 & 42.2 \\
1.6 & EROI with embodied energy $(1.1 /(1.2+1.3+1.4))$ & 38.5 & 39.0 & 39.3 \\
\hline
\end{tabular}

\section{Discussion and Conclusions}

According to the calculations, hydrocarbon production EROI over the past three years increased in the companies "Gazprom neft". In other companies, despite all efforts to increase the energy efficiency of production, EROI has decreased (Tables 14 and 15). It is an objective trend caused by the fact that most developing fields are in the third and fourth stage when production rates are decreasing and the water cut is rising. We can say that no company can escape the decrease of the EROI in oil production, it is inevitable. Companies can only focus their efforts on reducing the rate of decline, and we must say, Russian companies are successful in that.

Table 14. EROI $^{\mathrm{dev}}$ for hydrocarbon in Russia.

\begin{tabular}{llccc}
\hline No. & Company Name & $\mathbf{2 0 1 0}$ & $\mathbf{2 0 1 1}$ & $\mathbf{2 0 1 2}$ \\
\hline 1 & Gaspromneft & 29.9 & 35.0 & 35.4 \\
2 & Bashneft & - & 24.5 & 24.3 \\
3 & Rosneft & 22.2 & 21.8 & 21.6 \\
4 & TNK-BP & - & - & 22.8 \\
5 & Tatneft & 38.5 & 39.0 & 39.3 \\
6 & EROI $^{\text {dev and transp }}$ for hydrocarbon according to Rosstat's data & 32 & 33 & 30 \\
\hline
\end{tabular}

Table 15. EROI ${ }^{\text {basic mod }}$ for light oil products in Russia.

\begin{tabular}{llccc}
\hline No. & Company Name & $\mathbf{2 0 1 0}$ & $\mathbf{2 0 1 1}$ & $\mathbf{2 0 1 2}$ \\
\hline 1 & Gaspromneft & 13.5 & 13.7 & 13.3 \\
2 & Bashneft & & 5.8 & 5.6 \\
3 & Rosneft & 9.2 & 9.1 & 8.9 \\
4 & TNK-BP & - & - & 8.5 \\
5 & Tatneft & - & - & - \\
\hline
\end{tabular}

Another aspect that requires a further study is the EROI of oil light products. By our calculations, it has been decreasing in all companies. To analyze it we need additional data for various technological processes of oil refining. There isn't such data in the public domain. 
By itself, Russia's average EROI ${ }^{\text {dev and transp }}$ of hydrocarbon production is high due to the high EROI of gas production. Therefore, taken together, the oil and gas EROI is at 30-33. While taken separately, the EROI of oil production is about 20-25, and gas is above 33 .

When comparing our results with the average value of hydrocarbon production EROI in Russia, it should be noted that only the "Gazprom neft" values are higher than the average. Values for "Tataneft" are high only because there is no data on full energy consumption including thermal energy. However, the average EROI includes production and transportation energy costs and with adding transportation cost the EROI of "Gazprom neft" will be lower than 30.

When the light oil reserves run out and the extraction of heavy oil previously considered as unprofitable, we should pay special attention to the energy efficiency of hydrocarbon production. Calculating the EROI for oil and gas companies should be the same standard as the calculation of economic efficiency, ROI. The EROI calculations will tell us about the efforts that were made to improve the energy efficiency of production. It is not enough to say that the company in the reporting year saved a certain amount of energy, it is necessary to make a comparative estimation, and show how this saving has affected to the company's operations in general. The basis for such calculations have already been made by Russian companies.

In the future, it will be necessary to speak about the full energy audit, and this must become common practice, like a tax audit. Currently, companies do not provide enough data for a full energy audit. The following data should be published for an energy audit:

- Energy consumption by different sectors: exploration and production, refining, transportation and sales;

- Energy consumption by different processes within sectors;

- The material consumption, purchased equipment.

For an in-depth analysis, the energy and material consumption must be given separately for every production region and even field by field.

Furthermore, the introduction of energy-based calculation of recoverable reserves should be considered. Currently, recoverable reserves are calculated on the basis of economic profitability, along with this should be a calculation on the basis of recoverable reserves of energy profitability (Figure 5) [19].

Figure 5. Geological reserves, energetically and economically recoverable oil reserves ratio.

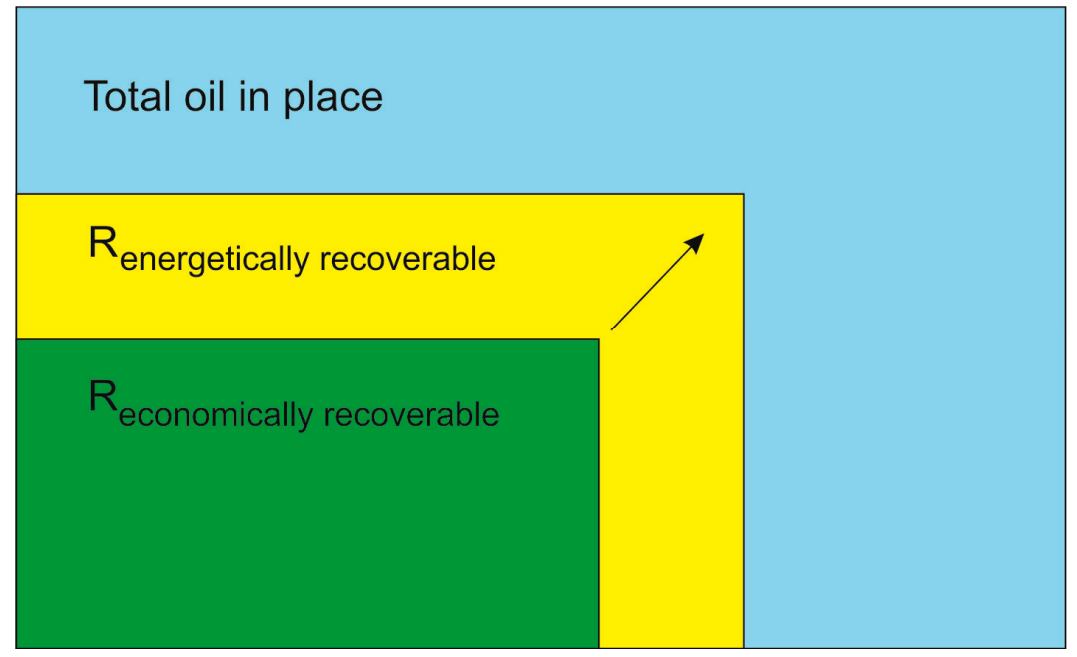


In this case, we will have two estimates of recoverable reserves: the economically and energetically profitable. Then, we should develop an economic mechanism that would stimulate companies to produce hydrocarbons to the energy efficiency limit. Thus, the principle of rational oil and gas production will be realized.

\section{Author Contributions}

Alexander Safronov-overall coordination of research and editing, text for 1 and 5 . Anton Sokolov-idea of research, data gathering, calculations, text for 2, 3, 4.

\section{Conflicts of Interest}

The authors declare no conflicts of interest.

\section{References}

1. Korzubaev, A.G. Russian Oil and Gas Industry in Transformation of World Energy Supply; Kontorovich, A.E., Ed.; Academic Publishing House “Geo": Novosibirsk, Russia, 2007.

2. BP statistical review of world energy 2013. Available online: http://www.bp.com/content/

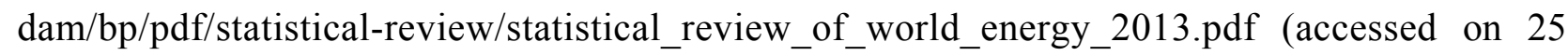
February 2014).

3. Sokolov, A.N.; Kochurov, B.I. Some aspects of the problem of peak oil production in the context of "economy of Meek". Probl. Reg. Ecol. 2013, 2, 7-14.

4. Murphy, D.J.; Hall, C.A.S. Year in review-EROI or energy return on (energy) invested. Ann. N. Y. Acad. Sci. 2010, 1185, 102-118.

5. Adam, R. Brandt Oil Depletion and the Energy Efficiency of Oil Production: The Case of California. Sustainability 2011, 3, 1833-1854.

6. Guilford, M.C.; Hall, C.A.S.; O’Connor, P.; Cleveland, C.J. A New Long Term Assessment of Energy Return on Investment (EROI) for U.S. Oil and Gas Discovery and Production. Sustainability 2011, 3, 1866-1887.

7. Moerschbaecher, M.; Day, J.W., Jr. Ultra-Deepwater Gulf of Mexico Oil and Gas: Energy Return on Financial Investment and a Preliminary Assessment of Energy Return on Energy Investment. Sustainability 2011, 3, 2009-2026.

8. Grandell, L.; Hall, C.A.S.; Höök, M. Energy Return on Investment for Norwegian Oil and Gas from 1991 to 2008. Sustainability 2011, 3, 2050-2070.

9. Cleveland, C.J.; O’Connor, P.A. Energy Return on Investment (EROI) of Oil Shale. Sustainability 2011, 3, 2307-2322.

10. Hu, Y.; Feng, L.Y.; Hall, C.C.S.; Tian, D. Analysis of the Energy Return on Investment (EROI) of the Huge Daqing Oil Field in China. Sustainability 2011, 3, 2323-2338.

11. Russian Statistic Agency. Available online: http://www.gks.ru/free_doc/new_site/business/prom/ en_balans.htm (accessed on 25 February 2014). 
12. OJSC "Gazprom Neft" 2012 Annual Report. Available online: http://ir.gazprom-neft.ru/ fileadmin/user_upload/documents/shareholders_meetings/Gazprom-Neft_Annual_Report_2012_ eng_web.pdf (accessed on 25 February 2014).

13. OJSC "Bashneft" 2012 Sustainability Report. Available online: http://www.bashneft.com/files/ iblock/0d8/OUR_2012_en.pdf (accessed on 25 February 2014).

14. OJSC "Rosneft" Annual Reports. Available online: http://www.rosneft.com/Investors/ results_and_presentations/annual_reports/ (accessed on 25 February 2014).

15. OJSC “TNK-BP” 2012 Annual report. Available online: http://rid.ru/wp-content/uploads/2014/07/ \%D0\%93\%D0\%9E-2012-\%D0\%A2\%D0\%9D\%D0\%9A-\%D0\%92\%D0\%A0-\%D0\%A5\%D0\% BE\%D0\%BB\%D0\%B4\%D0\%B8\%D0\%BD\%D0\%B3.pdf (accessed on 25 February 2014).

16. OJSC "Tatneft" Annual Reports. Available online: http://www.tatneft.ru/storage/block_editor/ files/44e0b7c138657f79ff65784e2e97b7c881cb8acd.pdf (accessed on 25 February 2014).

17. Murphy, D.J.; Hall, C.A.S.; Dale, M.; Cleveland, C. Order from Chaos: A Preliminary Protocol for Determining the EROI of Fuels. Sustainability 2011, 3, 1888-1907.

18. Geoff, H.; Craig, J. Report ICE: Inventory of Carbon and Energy. Department of Mechanical Engineering University of Bath, UK. Available online: http://www.bath.ac.uk/mech-eng/research/ sert/index.html (accessed on 25 February 2014).

19. Safronov, A.F.; Sokolov, A.N. Allocation of category of energy profitable recoverable oil reserves. Available online: http://www.ngtp.ru/rub/8/21_2013.pdf (accessed on 25 February 2014).

(C) 2014 by the authors; licensee MDPI, Basel, Switzerland. This article is an open access article distributed under the terms and conditions of the Creative Commons Attribution license (http://creativecommons.org/licenses/by/3.0/). 